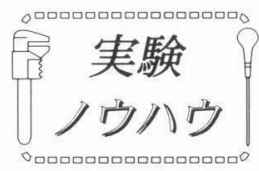

\section{試料加熱方式について 一傍熱型ヒーター一}

黒 河 明

電子技術総合研究所

『 305-8568 つくば市梅園 1-1-4

（1997 年 11 月 19 日受理）

\section{The Method of Sample Heating -Indirect Heating-}

Akira KUROKAWA

Electrotechnical Laboratory

1-1-4 Umezono, Tsukuba, Ibaraki 305-8568

(Received November 19, 1997)

試料の加熱方式としてヒーター面に試料を接触させる 試料加熱方式を紹介する。使用目的は試料の真空中での 加熱清浄化と酸化䨌囲気中での加熱である。

熱源としてはPBN/PG（Pyrolytic Boron Nitride/Pyrolytic Graphite）セラミックヒーターを使用している。こ のセラミックヒーターは積層構造で, PBN 基板上に PG でヒーターパターンを形成しその上に PBN のオーバー コートを行っており, 表面にはヒーターが露出していな い。PBN の特徴は, 耐高温, 耐熱衝撃, 耐酸化, 低ア ウトガス, 高純度, 化学的不活性であり, さらに軸方位 によっては良熱伝導性, 高電気絶縁性を示す。そのため るつぼ材として用いられヒーターの保護材としても適し ている。このセラミックヒーターの形状の自由度は大き く, 現在様々な形状や大きさのものが市販されている。

このセラミックヒーターによる加熱方式の利点は, 幅 広い種類の試料を加熱対象に選べ絶縁体でも加熱できる ことや試料形状の自由度が大きいこと, 輻射式よりも加 熱の効率がよいことである。また試料電位をヒーター電 位から絶縁できるため通電による昇温加熱中でも電子分 光による測定が行える。また温度分布についてもヒータ 一のパターンを適切に設計すればその一様性を最適化で きる。さらに酸化雾囲気に対しても PBN コートしてい るためヒーターの損耗がなくヒーターからの污染は起こ らない。

このセラミックヒーターを分析機器メーカー標準形状 のホルダー上に設置して使用している（Fig. 1)。電流導
表面科学 Vol. 19, No. 2, p. 129, 1998

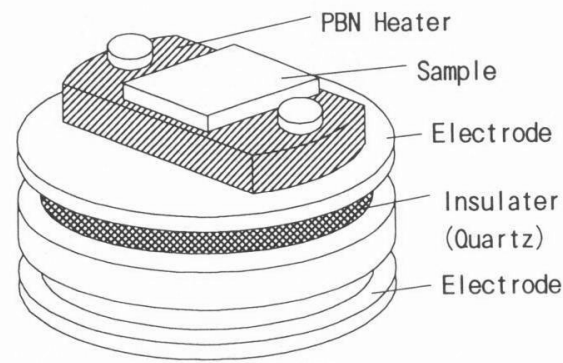

Fig. 1 Schematic view of sample-heating holder.

入は金属製ホルダーの上下から行い，石英によって電極 間を熱的電気的に絶緣している。既存装置にはホルダー を受ける機構があるがその改造はホルダー上下間への電 流導入用の電極を追加するだけの簡単なものですみ, 既 存の標準試料ホルダーも従来通り使用できる。試料移動 も従来からのホルダー搬送機構がそのまま使用でき, た とえば試料導入室から分析室への搬送にも何ら問題な く, 迅速な試料の交換の必要な多数試料の加熱 - 分析時 に重宝している。

昇温や冷却の温度制御はパソコンによる電源の制御で 行っている。これに真空度測定を加えることで超高真空 での脱ガス処理および加熱清浄化処理 $\left(500^{\circ} \mathrm{C}\right.$ まで昇温 $5^{\circ} \mathrm{C}$ 每分, $500^{\circ} \mathrm{C} 4$ 時間保持, $1200^{\circ} \mathrm{C}$ まで昇温 $100^{\circ} \mathrm{C}$ 毎 分, 冷却 $100^{\circ} \mathrm{C}$ 毎分, 処理中真空度が $10^{-7} \mathrm{~Pa}$ を越えな いように温度制御する）等のルーチンワークを深夜自動 運転で行っている。またパソコンによってヒーター温度 を簡易的に求めることができる。それにはヒーター電流 とその両端電圧降下を計測しヒーター抵抗値を求め, あ らかじめ求めておいたヒーター抵抗值とヒーター温度の 関数から逆算してヒーター温度を推定するわけである。 これにより試料の温度設定を単に印加電流（電圧）で設 定するだけでなくヒーター温度から制御することができ る。ただし厳密な温度制御には熱電対や放射温度計によ る監視が必要である。

使用にあたっての留意点として, 試料は BN と反応が 起こらないものであること, 試料電位を設定するには試 料への金属電極の接触が避けられないこと, 試料とヒー ターが直接接触するのでヒーター表面の污染には十分気 をつけること, 急激な電力投入で試料融点もしくは化合 物形成温度を超えないように留意すること, セラミック とはいえそれほど硬くないので傷つけないようにするこ とである。また酸化雾囲気中で高温加熱するときには, 試料を固定する押さえが酸化・高温に強いことが必要と なる。 